УДК 616.314.17-008.1:611.018.5:611.31:612.122

DOI 10.11603/2311-9624.2020.3.11568

(С). М. Шевчук, Т. І. Пупін, Н. Н. Бандрівська

Львівський національний медичний університет імені Данила Галицького e-mail: maryanashevchuk4@gmail.com

\title{
Визначення значень показників стрес-факторів у цієнтів Львівської обласної клінічної лікарні з дистрофічно-запальними захворюваннями тканин пародонта в крові та ротовій рідині
}

\section{ІНФОРМАЦІЯ}

Надійшла до редакції/Received: 08.082020 p.

Ключові слова: дистрофічно-запальні захворювання тканин пародонта; а-амілаза; глюкоза; кортизол; соматичні захворювання.
Вступ. Сучасна медицина накопичила безліч клінічних свідчень патогенетичних взаємозв’язків між захворюваннями внутрішніх органів і ураженнями тканин пародонта

\section{АНОТАЦІЯ}

Резюме. 3 метою вивчення стресогенних факторів у крові й ротовій рідині осіб із дистрофічно-запальними захворюваннями тканин пародонта, які перебували на лікуванні в різних відділеннях Львівської обласної клінічної лікарні (ЛОКЛ), визначали активність а-амілази, вмісту глюкози та кортизолу.

Мета дослідження - вивчити значення показників стрес-факторів у пацієнтів ЛОКЛ із дистрофічно-запальними захворюваннями тканин пародонта.

Матеріали і методи. Активність а-амілази та концентрацію глюкози у крові та ротовій рідині людей з’ясовували ензиматичним колометричним методом. Обчислення концентрації кортизолу в крові та ротовій рідині хворих здійснювали за допомогою твердофазного імуноферментного аналізу на апаратіStatFax-303 з використанням тест набору “Стероид ИФА-кортизол» фірми «Алкор-Био». Забір крові у хворих виконувався вранці, натще, після 12-годинної перерви в їжі, з ліктьової вени, ротову рідину для досліджень збирали ранком натще, шляхом спльовування у мірні пробірки, без стимуляції. Для оцінки ступеня вірогідності отриманих результатів дослідження використовували варіаційно-статистичний метод аналізу за допомогою Microsoft Excel. Статистичне обчислення результатів клінічних і лабораторних досліджень здійснювали за загальноприйнятими методами.

Результати досліджень та їх обговорення. Активність а-амілази в середньому у хворих із дз3ТП була вище, порівняно з контролем: у крові - у 1,5 раза, $\mathrm{p}<0,01$ та у ротовій рідині - у 2,0 рази, $\mathrm{p}<0,05$. Вміст глюкози у середньому в пацієнтів із дистрофічно-запальними захворюваннями тканин пародонта (ДЗ3ТП) при різних загальносоматичних захворюваннях був вище, порівняно з відповідними даними у контрольній групі: в крові - у 1,3 раза, $\mathrm{p}<0,05$ та в ротовій рідині - у 1,8 раза, $\mathrm{p}<0,01$. Вміст кортизолу в середньому у хворих із ДзЗТП був вище, порівняно з даними осіб контрольної групи: у крові - 1,5 раза та в ротовій рідині - у 1,8 раза, $\mathrm{p}<0,05$.

Висновки. Збільшення активності а-амілази, концентрацій глюкози та кортизолу в пацієнтів із захворюваннями тканин пародонта у крові та ротовій рідині можуть свідчити про зниження стресостійкості організму і бути об'єктивними маркерами стресогенного впливу на організм, зумовленого взаємообтяжуючим впливом соматичних і пародонтологічних захворювань.
[1, 2]. Давно були помічені асоціації запального процесу в пародонті з такими загальними захворюваннями, як цукровий діабет, нецукровий діабет, гіпо- та гіперфункція щитопо- 
дібної залози, гіперпаратиреоз різного генезу [3], хвороба Іценка - Кушинга, серцево-судинні захворювання (СС3) [4], нейровегетативні розлади, ураження органів травлення, в тому числі гепатобіліарної системи [5], ниркова недостатність різного генезу, захворювання системи крові й гемостазу $[1,6]$, системні захворювання сполучної тканини [7].

Незважаючи на досягнення у сучасній медицині, досить обмежено в клінічній стоматології використовують системний підхід [8] у лікуванні та профілактиці захворювань тканин пародонта і трактують їх генез з локальних позицій [9]. Нерідко не враховується спільність провідних механізмів, що ініціюють розвиток патологічних процесів у різних органах та тканинах організму [10]. Помилковою є оцінка патологічних змін в органах ротової порожнини як вторинних, тобто ускладнень захворювань інших систем організму [11]. Тому задля цього було проведено вивчення стресогенних факторів у крові й ротовій рідині осіб із дистрофічно-запальними захворюваннями тканин пародонта, які перебували на лікуванні в різних відділеннях Львівської обласної клінічної лікарні (ЛОКЛ).

Метою дослідження було вивчити значення показників стрес-факторів у пацієнтів лоКЛ із дистрофічно-запальними захворюваннями тканин пародонта.

Матеріали і методи. Дослідження проведенно у 36 осіб із серцево-судинними, 35 хво- рих - із неврологічними, у 36 досліджуваних - 3 гастроентерологічними та у 37 людей - iз ревматологічними захворюваннями, котрі перебували на лікуванні в ЛОКЛ. Отримані дані порівнювали зі значеннями в 30-ти соматично і стоматологічно здорових осіб (контрольна група). Активність а-амілази та концентрацію глюкози у крові та ротовій рідині людей з'ясовували ензиматичним колометричним методом [4, 12]. Обчислення концентрації кортизолу в крові та ротовій рідині хворих здійснювали за допомогою твердофазного імуноферментного аналізу на апараті StatFax-303 3 використанням тест набору «Стероид ИФАкортизол» фірми «Алкор-Био» [12, 13]. Забір крові у хворих виконували вранці, натще, після 12-годинної перерви в їжі, з ліктьової вени, ротову рідину для досліджень збирали ранком натще, шляхом спльовування у мірні пробірки, без стимуляції. Для оцінки ступеня вірогідності отриманих результатів дослідження використовували варіаційно-статистичний метод аналізу за допомогою Microsoft Excel. Статистичне обчислення результатів клінічних і лабораторних досліджень здійснювали за загальноприйнятими методами.

Результати досліджень та їх обговорення. У хворих із дистрофічно-запальними захворюваннями тканин пародонта (ДЗ3ТП) різних відділень локЛ зміни параметрів стресфакторів у крові та ротовій рідині носили більш виражений характер (табл.).

таблищя. Значення показників стрес-факторів у пацієнтів Львівської обласної клінічної лікарні з дистрофічно-запальними захворюваннями тканин пародонта

\begin{tabular}{|c|c|c|c|c|c|c|c|c|c|c|}
\hline \multirow{2}{*}{ Показник } & \multicolumn{2}{|c|}{$\begin{array}{c}\text { Серцево-судинні } \\
\text { захворювання }\end{array}$} & \multicolumn{2}{|c|}{$\begin{array}{c}\text { Неврологічні за- } \\
\text { хворювання }\end{array}$} & \multicolumn{2}{|c|}{$\begin{array}{c}\text { Гастроентероло- } \\
\text { гічні } \\
\text { захворювання }\end{array}$} & \multicolumn{2}{|c|}{$\begin{array}{c}\text { Ревматологічні } \\
\text { захворювання }\end{array}$} & \multicolumn{2}{|c|}{$\begin{array}{c}\text { Контрольна } \\
\text { група }\end{array}$} \\
\hline & кров & $\begin{array}{l}\text { ротова } \\
\text { рідина }\end{array}$ & кров & $\begin{array}{l}\text { ротова } \\
\text { рідина }\end{array}$ & кров & $\begin{array}{l}\text { ротова } \\
\text { рідина }\end{array}$ & кров & $\begin{array}{l}\text { ротова } \\
\text { рідина }\end{array}$ & кров & $\begin{array}{l}\text { ротова } \\
\text { рідина }\end{array}$ \\
\hline $\begin{array}{l}\text { а-амілаза } \\
\text { (Од/л) }\end{array}$ & $\begin{array}{c}79,63 \pm \\
5,24^{\circ}\end{array}$ & $\begin{array}{c}108,02 \pm \\
8,06^{\circ}\end{array}$ & $\begin{array}{c}80,95 \pm \\
5,25^{\circ}\end{array}$ & $\begin{array}{c}105,30 \pm \\
7,70^{\circ}\end{array}$ & $\begin{array}{c}74,85 \pm \\
4,37^{\circ}\end{array}$ & $\begin{array}{c}100,24 \pm \\
7,16^{\circ}\end{array}$ & $\begin{array}{c}84,20 \pm \\
5,33^{\circ}\end{array}$ & $\begin{array}{c}109,70 \pm \\
7,75^{\circ}\end{array}$ & $\begin{array}{c}51,80 \pm \\
4,07\end{array}$ & $\begin{array}{c}71,88 \pm \\
10,24\end{array}$ \\
\hline $\begin{array}{l}\text { Глюкоза } \\
\text { (ммоль/л) }\end{array}$ & $\begin{array}{l}5,46 \pm \\
0,46^{\circ}\end{array}$ & $\begin{array}{l}0,47 \pm \\
0,04^{\circ}\end{array}$ & $\begin{array}{l}5,20 \pm \\
0,27^{\circ}\end{array}$ & $\begin{array}{l}0,40 \pm \\
0,03^{\circ}\end{array}$ & $\begin{array}{l}5,18 \pm \\
0,20^{\circ}\end{array}$ & $\begin{array}{l}0,41 \pm \\
0,03^{\circ}\end{array}$ & $\begin{array}{l}5,36 \pm \\
0,25^{\circ}\end{array}$ & $\begin{array}{l}0,46 \pm \\
0,03^{\circ}\end{array}$ & $\begin{array}{c}4,15 \pm \\
0,40\end{array}$ & $\begin{array}{c}0,24 \pm \\
0,06\end{array}$ \\
\hline $\begin{array}{l}\text { Кортизол } \\
\text { (нг/мл) }\end{array}$ & $\begin{array}{c}412,90 \pm \\
52,30^{\circ}\end{array}$ & $\begin{array}{c}20,43 \pm \\
2,58^{\circ}\end{array}$ & $\begin{array}{c}376,59 \pm \\
50,22\end{array}$ & $\begin{array}{c}17,65 \pm \\
2,05^{\circ}\end{array}$ & $\begin{array}{c}382,63 \pm \\
47,12\end{array}$ & $\begin{array}{c}18,90 \pm \\
1,25^{\circ}\end{array}$ & $\begin{array}{c}402,45 \pm \\
50,28^{\circ}\end{array}$ & $\begin{array}{c}20,97 \pm \\
3,37^{\circ}\end{array}$ & $\begin{array}{c}261,50 \pm \\
42,80\end{array}$ & $\begin{array}{c}11,38 \pm \\
1,91\end{array}$ \\
\hline
\end{tabular}

Примітка. ${ }^{\circ} \rho<0,01$; ${ }^{\circ 0} \rho<0,05$ - достовірна різниця значень стосовно даних контрольної групи.

Так, у хворих із дз3ТП визначали суттєве зростання активності а-амілази у крові, порівняно 3 даними у контрольній групі, при максимальних значеннях цього параметра у пацієнтів із ревматологічними хворобами

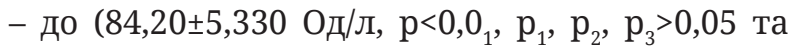
найнижчих у осіб із гастроентерологічними захворюваннями - $(74,85 \pm 4,37)$ Од/л, $\mathrm{p}<0,01, \mathrm{p}_{1}$, $\mathrm{p}_{2}, \mathrm{p}_{3}>0,05$. 
У ротовій рідині досліджуваних спостерігалась аналогічна тенденція, яка характеризувалась найнижчими значеннями активності a-амілази у ротовій рідині хворих із гастроентерологічною патологією - $(100,24 \pm 7,16)$ Од/л, $\mathrm{p}<0,05, \mathrm{p}_{1}, \mathrm{p}_{2}>0,05$ та максимальними даними в осіб із ревматологічними ураженнями з ДЗЗТП - до $(109,70 \pm 7,75)$ Од/л, $\mathrm{p}<0,05, \mathrm{p}_{1}, \mathrm{p}_{2}$, $\mathrm{p}_{3}>0,05$.

У середньому в пацієнтів із дз3ТП активність а-амілази була вище, порівняно з контрольною групою: у крові - у 1,5 раза, $\mathrm{p}<0,01$ та У ротовій рідині - у 2,0 рази, $\mathrm{p}<0,05$.

Ми визначили достовірне зростання рівня глюкози у крові пацієнтів із ДЗзТП різних відділень ЛОКЛ: від $(5,18 \pm 0,20)$ ммоль/л у осіб iз гастроентерологічними захворюваннями, $\mathrm{p}<0,05, \mathrm{p}_{1}, \mathrm{p}_{2}>0,05$ до 5,46 $\pm 0,40$ у досліджуваних із CCX, $\mathrm{p}<0,05$, порівняно 3 даними в осіб контрольної групи.

Максимальне підвищення вмісту глюкози у ротовій рідині визначали в осіб із дЗЗТП при серцево-судинних захворюваннях - до $(0,47 \pm 0,04)$ ммоль/л, $р<0,01$. При цьому найнижчі значення даного параметра в ротовій рідині спостерігались у хворих із дЗ3ТП 3 неврологічними ураженнями - $(0,40 \pm 0,03)$ ммоль/л, $\mathrm{p}<0,05, \mathrm{p}_{1}>0,05$.

У середньому в пацієнтів із дзЗТП при різних загальносоматичних захворюваннях вміст глюкози був вище, порівняно з відповідними даними у контрольній групі: у крові - у 1,3 раза, $\mathrm{p}<0,05$ та у ротовій рідині - у 1,8 раза, $\mathrm{p}<0,01$.
Вміст кортизолу в крові досліджуваних із ДЗ3ТП різних відділень ЛОКЛ достовірно зростав, порівняно з даними у контрольній групі, й характеризувався найбільшими значеннями в осіб із серцево-судинними хворобами $(412,90 \pm 52,30)$ нг/мЛ, $\mathbf{p}<0,05$, при мінімальних даних у осіб із дзЗТП з неврологічними захворюваннями - $(376,59 \pm 50,22)$ нг/мл, p, p $>0,05$.

Концентрація кортизолу в ротовій рідині досліджуваних із дз3ТП збільшувалась порівняно 3 даними в осіб контрольної групи. При цьому в пацієнтів із дз3ТП відділень ССХ та ревматології вміст кортизолу в ротовій рідині був практично однаковим та найбільшим - $(20,43 \pm 2,58)$ нмоль/л, $\mathrm{p}<0,05$ та $(20,97 \pm 3,37)$ нмоль/л, $\mathrm{p}<0,05, \mathrm{p}_{1}, \mathrm{p}_{2}, \mathrm{p}_{3}>0,05$ відповідно. Найменше значення цього параметра було визначено у ротовій рідині осіб із неврологічними хворобами - $(17,65 \pm 2,05)$ нмоль/л, $p<0,05$, $\mathrm{p}_{1}>0,05$.

У середньому в пацієнтів із дзЗТП вміст кортизолу був вище, порівняно 3 даними в осіб контрольної групи: у крові - 1,5 раза та в ротовій рідині - у 1,8 раза, $\mathrm{p}<0,05$.

Висновки. Збільшення активності а-амілази, концентрацій глюкози та кортизолу в пацієнтів із захворюваннями тканин пародонта у крові та ротовій рідині можуть свідчити про зниження стресостійкості організму і бути об'єктивними маркерами стресогенного впливу на організм, зумовленого взаємообтяжуючим впливом соматичних і пародонтологічних захворювань.

(С). Н. Шевчук, Т. И. Пупин, Н. Н. Бандривская

Львовский национальный медицинский университета имени Данила Галицкого

\section{Определение значений показателей стресс-факторов у пациентов Львовской областной клинической больницы с дистрофически- воспалительными заболеваниями тканей пародонта в крови и ротовой жидкости}

Резюме. С целью изучения стрессогенных факторов в крови и ротовой жидкости лиц с дистрофическивоспалительными заболеваниями тканей пародонта, находившихся на лечении в различных отделениях Львовской областной клинической больницы (ЛОКБ), определяли активность а-амилазы, содержания глюкозы и кортизола.

Цель исследования - изучить значения показателей стресс-факторов у пациентов ЛокБ с дистрофически-воспалительными заболеваниями тканей пародонта.

Материалы и методы. Активность а-амилазы и концентрацию глюкозы в крови и ротовой жидкости людей выясняли энзиматическим колометрическим методом. Вычисления концентрации кортизола в крови и ротовой жидкости больных осуществляли с помощью твердофазного иммуноферментного анализа на апарате StatFax-303 с использованием тест набора «Стероид ИФА-кортизол» фирмы «Алкор-Био». Забор крови у больных выполнялся утром, натощак, после 12-часового перерыва в еде, из 
локтевой вены, ротовую жидкость для исследований собирали утром натощак, путем сплевывания в мерные пробирки, без стимуляции. Для оценки степени достоверности полученных результатов исследования использовали вариационно-статистический метод анализа с помощью Microsoft Excel. Статистическое вычисление результатов клинических и лабораторных исследований осуществляли с общепринятыми методами.

Результаты исследований и их обсуждение. Активность а-амилазы в среднем у пациентов с дистрофически-воспалительными заболеваниями тканей пародонта (ДВЗТП) была выше, по сравнению с контролем: в крови - в 1,5 раза, p<0,01 и в ротовой жидкости - в 2,0 раза, p<0,05. Содержание глюкозы в среднем у больных ДВЗТП при различных общесоматических заболеваниях был выше, по сравнению с данными в контроле: в крови - в 1,3 раза, p<0,05 и в ротовой жидкости - в 1,8 раза, p<0,01. Содержание кортизола в среднем у больных ДВЗТП был выше, по сравнению с данными у лиц контрольной группы: в крови - 1,5 раза и в ротовой жидкости - в 1,8 раза, $\mathrm{p}<0,05$.

выводы. Увеличение активности а-амилазы, концентраций глюкозы и кортизола у пациентов с заболеваниями тканей пародонта в крови и ротовой жидкости могут свидетельствовать о снижении стрессоустойчивости организма и быть объективными маркерами стрессогенного воздействия на организм, обусловленного взаимообтяжующим влиянием соматических и пародонтологических заболеваний.

Ключевые слова: дистрофически-воспалительные заболевания тканей пародонта; а-амилаза; глюкоза; кортизол; соматические заболевания.

\author{
(C). M. Shevchuk, T. I. Pupin, N. N. Bandrivska
}

Danylo Halytskyi Lviv National Medical University

\title{
Determination of values of stress-factors in patients of Lviv Regional Clinical Hospital with dystrophic and inflammatory diseases of periodontal tissues in the blood and oral cavity
}

Summary. In order to study stressors in the blood and oral fluid of persons with dystrophic and inflammatory diseases of periodontal tissues, who were treated in different departments of Lviv Regional Clinical Hospital (LRCH), the activity of a-amylase, glucose and cortisol was determined.

The aim of the study - determination of values of stress factors in patients of LRCH with dystrophicinflammatory diseases of periodontal tissues.

Materials and Methods. a-amylase activity and glucose concentration in human blood and oral fluid were determined by enzymatic colometric method. The calculation of the concentration of cortisol in the blood and oral fluid of patients was performed using solid-phase enzyme-linked immunosorbent assay on a device StatFax 303 using a test kit "Steroid ELISA-cortisol" company Alcor-Bio. Blood sampling in patients was performed in the morning, on an empty stomach, after a 12-hour break in food, from the ulnar vein, oral fluid for research was collected in the morning on an empty stomach, by spitting into measuring tubes, without stimulation. To assess the probability of the obtained results of the study used a variational-statistical method of analysis using Microsoft Excel. Statistical calculation of the results of clinical and laboratory studies was carried out according to conventional methods.

Results and Discussion. On average, $a$-amylase activity in patients with dystrophic-inflammatory diseases of periodontal tissues was higher compared to control: in the blood -1.5 times, $p<0.01$ and in oral fluid -2.0 times, $\mathrm{p}<0.05$. Glucose content on average, in patients with dystrophic-inflammatory diseases of periodontal tissues in various somatic diseases was higher than the corresponding data in the control: in the blood - 1.3 times, $\mathrm{p}<0.05$ and in the oral fluid -1.8 times, $\mathrm{p}<0.01$. The content of cortisol on average in patients with dystrophic-inflammatory diseases of periodontal tissues was higher than in the control group: in the blood 1.5 times and in the oral fluid -1.8 times, $\mathrm{p}<0.05$.

Conclusions. Thus, increased a-amylase activity, glucose and cortisol concentrations in patients with periodontal diseases in the blood and oral fluid may indicate a decrease in stress resistance and be objective markers of stress on the body due to the aggravating effects of somatic and periodontal diseases.

Key words: dystrophic-inflammatory diseases of periodontal tissues; a-amylase; glucose; cortisol; somatic diseases. 


\section{СПИСОК ЛІТЕРАТУРИ}

1. Prevalence of the generalized periodontitis in patients with different groups blood in depending on age and periodontal biotype/Yu. L. Bandrivsky, O. O. Bandrivska, R. Yu. Shkrebnyuk, V. T. Dyryk // Wiadomości Lekarskie. - 2020. - No. 1 (73) - P. 119-122.

2. Armitage G. Analysis of gingival crevice fluid and risk of progression of periodontitis / G. Armitage // Periodontology. - 2000. - Vol. 34. - P. 109-119.

3. Nabors T. W. Salivary testing for periodontal disease diagnosis and treatment / T. W. Nabors, R. C. McGlennen, D. Thompson // Dent. Today. - 2010. - Vol. 29 (6). P. 53-60.

4. Kaufman E. Analysis of saliva for periodontal diagnosis - a review / E. Kaufman, I. B. Lamster // J. Clin. Periodontol. - 2000. - Vol. 27. - P. 453-465.

5. Вольф Г. Ф. Пародонтология / Г. Ф. Вольф, Э. М. Ратейцхак, К. Ратейцхак. - М. : МЕДпресс-информ, 2008. - 548 с.

6. Жулкевич I. В. Гематологічні аспекти остеопорозу / І. В. Жулкевич, Н. І. Корильчук // Лікарська справа. - 1999. - № 2. - С. 12-17.

7. Горбачева Л. А. Общесоматические аспекты патогенеза и лечения генерализованного пародонтита / Л. А. Горбачева, А. И. Кирсанов, Л. Ю. Орехова // Сто-

\section{REFERENCES}

1. Bandrivsky, Y.L., Bandrivska, O.O., Shkrebnyuk, R.Y., \& Dyryk, V.T. (2020). Prevalence of the generalized periodontitis in patients with different groups blood in depending on age and periodontal biotype. Wiadomosci lekarskie, 73 (1), 119-122.

2. Armitage, G. (2000). Analysis of gingival crevice fluid nd risk of progression of periodontitis. Periodontology, 34, 109-119.

3. Nabors, T.W., McGlennen, R.C., \& Thompson, D. (2010). Salivary testing for periodontal disease diagnosis and treatment. Dent. Today, 29 (6), 53-60.

4. Kaufman, E., \& Lamster, I.B. (2000). Analysis of saliva for periodontal diagnosis - a review. J. Clin. Periodontol., 27, 453-465.

5. Volf, G.F., \& Rateytskhak, E.M. (2008). Parodontologiya [Periodontology]. Moscow: MEDpress-inform [in Russian].

6. Zhulkevych, I.V., \& Korylchuk, N.I. (1999). Hematolohichni aspekty osteoporozu [Hematological aspects of osteoporosis]. Likarska sprava-Medicine, 2, 12-17 [in Ukrainian].

7. Horbacheva, L.A., Kyrsanov, A.Y., \& Orekhova, L.Yu. (2013). Obshchesomaticheskye aspekty patogeneza i lecheniya generalizovannogo parodontita [Somatic aspects of the pathogenesis and treatment of generalized матология. - 2013. - Т. 80, № 1. - С. 26-34.

8. Correspondence between dental and skeletal maturity parameters among patients with different sagittal relationships at the end of puberty period / M. Goncharuk-Khomyn, E. Akleyin, I. Zhulkevych [et al.] // J. Int. Dent. Med. Res. - 2020. - Vol. 13 (1). - P. 223228.

9. Данилевский Н. Ф. Заболевания пародонта / Н. Ф. Данилевский, А. В. Борисенко. - К. : Здоров’я, 2000. - 466 c.

10. Tonetti M. S. Staging and grading of periodontitis: Framework and proposal of a new classification and case definition / M. S. Tonetti, H. Greenwell, K. S. Kornman // J. Clin. Periodontol. - 2018. - Vol. 45. P. S149-S161.

11. Заболотний Т. Д. Запальні захворювання пародонта / Т. Д. Заболотний, А. В. Борисенко, Т. І. Пупін. - Львів : ГалДент, 2013. - 206 с.

12. Personalized medicine in dentistry/P.S.Pudakalkatti, A. S. Baheti, S. A. Hattarki [et al.] // J. Orofac. Sci. - 2017. - Vol. 9 (1). - P. 3.

13. Колб В. Г. Клиническая биохимия / В. Г. Колб, В. С. Камышников. - Минск : Ураджай, 1976. - 145 с.

periodontitis]. Stomatologiya - Dentistry, 80, 1, 26-34 [in Russian].

8. Goncharuk-Khomyn, M., Akleyin, E., Zhulkevych, I., Nahirnyi, Y., Brekhlichuk, P., Mochalov, Y., ..., \& Stoika, O. (2020). Correspondence between dental and skeletal maturity parameters among patients with different sagittal relationships at the end of puberty period. J. Int. Dent. Med. Res., 13 (1), 223-228.

9. Danylevskyy, N.F., \& Borysenko, A.V. (2000). Zabolevaniya parodonta [Periodontal disease]. Kyiv: Zdorovia [in Russian].

10. Tonetti, M.S., Greenwell, H., \& Kornman, K.S. (2018). Staging and grading of periodontitis: Framework and proposal of a new classification and case definition. $J$. Clin. Periodontol., 45, S149-S161.

11. Zabolotnyi, T.D., Borysenko, A.V. \& Pupin, T.I. (2013). Zapalni zakhvoriuvannia parodonta [Inflammatory periodontal diseases]. Lviv: HalDent [in Ukrainian].

12. Pudakalkatti, P.S., Baheti, A.S., Hattarki, S.A., \& Kambali, S.S. (2017). Personalized medicine in dentistry. J. Orofac. Sci., 9 (1), 3.

13. Kolb, V.G., \& Kamishnikov, V.S. (1976). Klinicheskaya biokhimiya [Clinical biochemistry]. Minsk: Uradzhay [in Russian]. 